\title{
Comparative infectivity of Fasciola hepatica metacercariae from isolates of the main and secondary reservoir animal host species in the Bolivian Altiplano high human endemic region
}

\author{
María Adela Valero and Santiago Mas-Coma
}

Department of Parasitology, Faculty of Pharmacy, University of Valencia, Av. Vicente Andrés Estellés s/n, 46100 Burjassot -
Valencia, Spain

Key words: Fasciola hepatica, metacercariae, Bolivian Altiplano, viability, age, sheep, cattle, pig, donkey, laboratory rat

\begin{abstract}
Fascioliasis due to Fasciola hepatica (Linnaeus, 1758) is an endemic disease on the Northern Bolivian Altiplano, where human prevalences and intensities are the highest known, sheep and cattle are the main reservoir hosts, and pigs and donkeys the secondary ones. Investigations were carried out to study the viability of metacercariae experimentally obtained from eggs shed by naturally infected Altiplanic sheep, cattle, pigs and donkeys. A total of 157 Wistar rats were infected with doses of 5, 10, 20 and 150 metacercariae. Metacercariae aged for different number of weeks were used to analyse the influence of age on their viability. The number of worms successfully developed in each rat was established by dissection. Results obtained show that metacercarial infectivity is dependent upon storage time, being lower when metacercariae are older. The maximum longevity is 31 weeks using doses of 20 metacercariae per rat and 48 weeks with 150 metacercariae per rat, although in the latter case only a very low percentage of worms is recovered. Age-related infectivity of metacercariae from Altiplanic $F$. hepatica does not significantly differ from that of the liver fluke in lowlands of other countries. Concerning the influence of the isolate according to host species, results indicate that metacercarial viabilities of pig and donkey isolates are similar to the viabilities of metacercariae of sheep and cattle isolates. Thus, pig and donkey have a high transmission potential capacity concerning this aspect. This fact is of great importance for the control of human and animal fascioliasis in this highly endemic zone.
\end{abstract}

Fascioliasis due to the digenean species Fasciola hepatica (Linnaeus, 1758) (Trematoda: Fasciolidae) has recently proved to be an important health problem, with human cases reported in countries of the five continents (Esteban et al. 1998), including severe symptomatology and pathology (Chen and Mott 1990, Mas-Coma et al. 1999a, 2000), with singular epidemiological characteristics (Mas-Coma et al. 1999a, b) and presenting human endemic areas ranging from hypo- to hyperendemic (Mas-Coma et al. 1999b). One of the singular epidemiological characteristics of human fascioliasis is the link of the hyperendemic areas to very high altitude regions, at least in South America (MasComa et al. 1999a).

The Northern Bolivian Altiplano, located at very high altitude (3800-4100 m) between lake Titicaca and the valley of the city of La Paz, presents the highest prevalences and intensities of human fascioliasis known (Hillyer et al. 1992, Mas-Coma et al. 1995, 1999c, Bjorland et al. 1995, Esteban et al. 1997a, b, 1999, O'Neill et al. 1998). Multidisciplinary studies were undertaken to disentangle how the liver fluke and its lymnaeid snail hosts adapted to the extreme environmental conditions of the high altitude and succeeded in giving rise to high infection rates (MasComa et al. 1999c). Intraspecific morphological variability studies showed no significant difference between $F$. hepatica adult flukes from Bolivia and Spain (Valero et al. 1999). Snail anatomy and shell morphology (Oviedo et al. 1995, Samadi et al. 1999), DNA sequencing (Bargues and Mas-Coma 1997, Bargues et al. 1997) and isoenzymatic studies (JabbourZahab et al. 1997) proved that Lymnaea truncatula (Müller, 1774) (Gastropoda: Basommatophora: Lymnaeidae) is the only intermediate host species in the Northern Bolivian Altiplano. Among the different potential animal definitive host species, coprological surveys showed that horses, llamas and alpacas (MasComa et al. 1997), as well as rabbits, wild hares, domestic guinea pigs and wild rodents (Fuentes et al. 1997) do not significantly participate in the transmission of the disease. According to livestock populations inhabiting the endemic region and to infection prevalences and intensities, sheep and cattle may be considered the main reservoir host species (Ueno and Morales 1973, Ueno et al. 1975, Mas-Coma et al. 1995, 1997, Hillyer et al. 1996, Buchon et al. 1997, Grock et al. 1998) and pigs and donkeys the secondary ones (Mas-Coma et al. 1997).

Among the research activities carried out to characterise the transmission pattern of the liver fluke in the Northern Bolivian Altiplano, special attention was paid to metacercariae. Because of their considerable survival potential, metacercariae are of major 
importance for the study of both the life history of the parasite and the epizootiology of fascioliasis (Kimura and Shimizu 1979). Metacercarial survival depends on the environ-mental conditions, particularly relative humidity (Boray and Enigk 1964, Meek and Morris 1979), temperature (Boray and Enigk 1964) and sunlight (Chowaniec 1968, Hodasi 1971). Their survival also varies according to the snail vector species involved (Harith 1977) and the age of the metacercariae (Over and Dijkstra 1975).

There are no data on viability and infectivity of $F$. hepatica metacercariae, either in the Altiplano or in other high altitude regions. Moreover, in lowlands of other countries, studies conducted to date only concerned metacercarial infectivity of ovine and bovine origins in both homologous and heterologous hosts (Dixon 1964, Knight 1978, Alcibar Mera et al. 1985). To our knowledge, nothing is known about the viability of metacercariae of liver fluke isolates from pig and donkey hosts. The present paper is a comparative experimental study of the viability of metacercariae produced under standardised conditions from liver fluke eggs shed by different Altiplanic host species. The different $F$. hepatica isolates were obtained from sheep, cattle, pigs and donkeys naturally parasitised in the Bolivian Altiplano endemic region. The influences of host species isolate and metacercarial age upon metacercarial viability were analysed.

\section{MATERIALS AND METHODS}

Parasites. Only Bolivian Altiplano strains of the parasite, $F$. hepatica, and of the molluscan intermediate host species, $L$. truncatula, were used. L. truncatula snails, which shed the cercariae that gave rise to the metacercariae studied, were from a strain laboratory-reared in climatic chambers (HPS1500 and HPS-500 models of Heraeus-Vötsch). Experimental condi-tions for snail rearing were: temperature $20^{\circ} \mathrm{C}$; photoperiod $12 \mathrm{~h} / 12 \mathrm{~h}$ light/darkness; relative humidity $90 \%$. These snails were monomiracidially infected with miracidia obtained from $F$. hepatica eggs found in naturally infected individuals of sheep, cattle, pigs and donkeys on the Bolivian Altiplano.

The metacercariae were stored in natural water in total darkness until required. The storage temperature selected was $4^{\circ} \mathrm{C}$ according to the mean winter temperature obtained in five meteorological stations of the Bolivian Altiplano endemic region in the 1949-1990 year period (Mas-Coma et al. 1999d). This temperature has also been used for storing metacercariae by other authors, thus enabling comparative analysis with lowland liver fluke isolates.

A total of 16 groups of metacercariae aged different number of weeks were used to study the influence of age on their viability: $1,2,6,7,8,9,10,11,12,27,29,30,31,32,40$ and 48 weeks (see Tables 1 and 2).

Experimental mammalian host. A total of 171 male Wistar rats (Iffa Credo, Barcelona, Spain) aged 4-5 weeks were used throughout. The animals were housed in MicroIsolator boxes (Iffa Credo, Barcelona, Spain) and maintained in a pathogen-free room, electrically heated with a $12 \mathrm{~h} / 12 \mathrm{~h}$ light/darkness cycle (conditions in compliance with the European Agreement of Strasbourg, 18 March 1986). Food and water were provided ad libitum.

Testing of metacercarial viability. Wistar rats were infected with doses of 5, 10, 20 or $150 \mathrm{~F}$. hepatica metacercariae per rat according to the experiment (see Tables 1 and 2). Infection prevalence and intensity (number of worms successfully developed in each rat) were established by dissection 9-12 weeks after infection. Metacercariae were inoculated orally by means of a gastric tube. The number of Wistar rats in each infection experiment varied according to the number of metacercariae available. The rats were sacrificed using an excess of ether anaesthesia, and $F$. hepatica worms were collected under a dissecting microscope. Initially the bile duct was examined for the presence of worms, though the rest of the organs were also evaluated. Afterwards, the thoracic and abdominal viscera and cavities were examined and thoroughly rinsed with water to assure the recovery of all worms.

Statistical procedures. Calculations were made of the total infectivity or percentage of successfully infected rats [\% $=$ (number of animals positive to infection/total number of animals inoculated) $\times 100$ ], total percentage of worms recovered $[\% \mathrm{wr}=$ (total number of flukes recovered/total number of cysts administered in all animals) $\times 100]$ and percentage of worms recovered per infected rat [\%wrir $=$ (flukes recovered/cysts administered per infected rat) $\times 100]$. Statistical analyses were performed using the SPSS 6.1 statistical package under Windows. Statistical comparisons of categorical variables were carried out with the chi-square test. Values were considered statistically significant when $\mathrm{p}<0.05$.

Calculation of $\boldsymbol{F}$. hepatica metacercarial survival at $4^{\circ} \mathrm{C}$ tested in vivo. Taking into account that metacercarial mortality is age-dependent, a modified version of the equation proposed by Smith (1982) was used: $\mathrm{C}(\mathrm{t})=\mathrm{Co} \mathrm{e}^{-(\delta) t}$, where Co $=$ the initial number of metacercariae. In our case $\delta=\mu_{1}+\beta \mathrm{H}$, where $\mu_{1}=$ the metacercarial mortality rate (cysts/week), and $\beta \mathrm{H}=$ the net rate of infection (cysts/rat/week). According to Over and Dijkstra (1975), the death rate was assumed to be age-independent; consequently, the mean probability of death during some defined interval is the same regardless of the age of the metacercariae. Data processing was carried out with SPSS 6.1 statistical package under Windows. Adjusted nonlineal curves were tested using the correlation coefficient $\left(\mathrm{R}^{2}\right)$ and the least squares residual (sse).

\section{RESULTS}

\section{Sheep and cattle isolates}

The results of the metacercarial infectivity from isolates of the main reservoir host species, sheep and cattle, are summarised in Table 1 . The results of $\%$ wr and \%wrir were lower when metacercariae were older. The maximum longevity was 31 weeks using doses of 20 metacercariae per rat and 48 weeks using doses of 150 metacercariae per rat. The exponential model of the form $\mathrm{C}(\mathrm{t})=\mathrm{Co}^{-(\delta) \mathrm{t}}$, where $\mathrm{Co}=21.7 \pm 3.0$ and $\delta=$ 
Table 1. Results obtained in the study of Wistar rats experimentally infected with Fasciola hepatica metacercariae of sheep and cattle isolates from the Bolivian Altiplano.

\begin{tabular}{|c|c|c|c|c|c|c|c|c|c|c|}
\hline \multirow{3}{*}{$\begin{array}{c}\text { Age of } \\
\text { metacercaria } \\
\text { e (weeks) }\end{array}$} & \multirow{3}{*}{ Isolate } & \multirow{3}{*}{$\mathrm{m} / \mathrm{r}$} & \multicolumn{3}{|c|}{ Prevalence } & \multicolumn{5}{|c|}{ Intensity } \\
\hline & & & \multirow[t]{2}{*}{ nrt } & \multirow[t]{2}{*}{ nri } & \multirow[t]{2}{*}{$\% \mathrm{i}$} & \multirow[t]{2}{*}{ range } & \multirow[t]{2}{*}{$\mathrm{X}$} & \multirow[t]{2}{*}{$\%$ wr } & \multicolumn{2}{|c|}{$\%$ wrir } \\
\hline & & & & & & & & & range & mean \\
\hline 1 & $\mathrm{~s}$ & 20 & 14 & 11 & 78.6 & $1-8$ & 3.6 & 14.3 & $5.0-40.0$ & 18.2 \\
\hline 2 & $\mathrm{~s}$ & 20 & 23 & 18 & 78.3 & $1-10$ & 3.7 & 14.6 & $5.0-50.0$ & 18.6 \\
\hline 6 & $\mathrm{c}$ & 20 & 4 & 4 & 100 & $1-2$ & 1.7 & 8.8 & $5.0-10.0$ & 8.8 \\
\hline 7 & $\mathrm{c}$ & 20 & 4 & 0 & 0.0 & 0 & 0.0 & 0.0 & 0.0 & 0.0 \\
\hline 8 & $\mathrm{c}$ & 20 & 4 & 2 & 50.0 & $1-2$ & 1.5 & 3.7 & $5.0-10.0$ & 7.5 \\
\hline 9 & $\mathrm{c}$ & 20 & 2 & 0 & 0.0 & 0 & 0.0 & 0.0 & 0.0 & 0.0 \\
\hline 10 & $\mathrm{c}$ & 20 & 4 & 0 & 0.0 & 0 & 0.0 & 0.0 & 0.0 & 0.0 \\
\hline 11 & $\mathrm{c}$ & 20 & 10 & 2 & 20.0 & 1 & 1.0 & 1.0 & 5.0 & 5.0 \\
\hline 12 & $\mathrm{~s}$ & 5 & 1 & 0 & 0.0 & 0 & 0.0 & 0.0 & 0.0 & 0.0 \\
\hline 12 & $\mathrm{~s}$ & 20 & 2 & 0 & 0.0 & 0 & 0.0 & 0.0 & 0.0 & 0.0 \\
\hline 27 & $\mathrm{c}$ & 20 & 4 & 2 & 50.0 & $1-2$ & 1.5 & 3.7 & $5.0-10.0$ & 7.7 \\
\hline 29 & $\mathrm{c}$ & 20 & 3 & 2 & 66.7 & 1 & 1.0 & 1.7 & 5.0 & 2.5 \\
\hline 30 & $\mathrm{c}$ & 20 & 9 & 4 & 44.4 & 1 & 1.0 & 0.5 & 5.0 & 1.0 \\
\hline 31 & $\mathrm{c}$ & 20 & 2 & 2 & 100 & 1 & 2.0 & 5.0 & 5.0 & 5.0 \\
\hline 32 & $\mathrm{~s}$ & 5 & 6 & 0 & 0.0 & 0 & 0.0 & 0.0 & 0.0 & 0.0 \\
\hline 32 & $\mathrm{~s}$ & 10 & 6 & 0 & 0.0 & 0 & 0.0 & 0.0 & 0.0 & 0.0 \\
\hline 32 & $\mathrm{~s}$ & 20 & 6 & 0 & 0.0 & 0 & 0.0 & 0.0 & 0.0 & 0.0 \\
\hline 40 & $\mathrm{~s}$ & 5 & 6 & 0 & 0.0 & 0 & 0.0 & 0.0 & 0.0 & 0.0 \\
\hline 40 & $\mathrm{~S}$ & 10 & 6 & 0 & 0.0 & 0 & 0.0 & 0.0 & 0.0 & 0.0 \\
\hline 40 & $\mathrm{~s}$ & 20 & 6 & 0 & 0.0 & 0 & 0.0 & 0.0 & 0.0 & 0.0 \\
\hline 48 & $\mathrm{~S}$ & 150 & 1 & 1 & 100 & 1 & 1.0 & 0.7 & 0.7 & 0.7 \\
\hline
\end{tabular}

$\mathrm{s}=$ sheep $; \mathrm{c}=$ cattle $; \mathrm{m} / \mathrm{r}=$ number of metacercariae inoculated per rat; $\mathrm{nrt}=$ total number of inoculated rats; nri $=$ number of rats infected; $\% \mathrm{i}=$ percentage of successfully infected rats [(number of rats positive to infection/total number of rats inoculated $) \times$ $100]$; range $=$ minimum and maximum number of worms recovered per rat; $X=$ mean number of worms recovered per rat; \%wr $=$ total percentage of worms recovered [(total number of flukes recovered/total number of cysts administered in all animals) $\times$ 100]; \%wrir range $=$ minimum and maximum percentages of worms recovered per infected rat [(flukes recovered/cysts administered per infected rat) $\times 100]$; \%wrir mean $=$ mean percentages of worms recovered per infected rat [(flukes recovered/cysts administered per infected rat) $\times 100]$.

$0.20+0.04\left(\mathrm{R}^{2}=0.81\right.$, sse: 59.59$)$, provided a good description of the relationship between $\% \mathrm{wr}$ and metacercarial age in weeks (Fig. 1). Thus, it may be concluded that under our standard conditions, metacercarial infectivity $(\% \mathrm{wr})$ is dependent upon storage time.

Our data enable to calculate the value of $\beta \mathrm{H}$, which could not be obtained by Smith (1982) because he only worked with data from metacercariae excysted in vitro. The values calculated by Smith (1982) regarding survival among metacercariae excysted in vitro showed that $\mu_{1}$ summer $=0.10 /$ cysts $/$ week and $\mu_{1}$ winter $=$ $0.07 /$ cysts/week. Since in our case $\delta=\mu_{1}+\beta \mathrm{H}$, the values of $\beta \mathrm{H}$ for the laboratory rat host would range from 0.10 to 0.13 .

\section{Pig isolate}

The results of metacercarial infectivity using the pig isolate are summarised in Table 2. Wistar rat susceptibility to pig isolates of 6-11 week old metacercariae (expressed as \% $\mathrm{i}$ ) was globally $45.8 \%$. No significant differences were detected between pig isolate $\% \mathrm{i}$ and cattle isolate \% $\mathrm{i}$ when comparing the same age periods by the chi-square test $(\alpha: 0.20)$. The global \%wr was 3.3\%. No significant differences were detected between pig and cattle isolate \%wr for the same age ranges $(\alpha: 0.44)$.

\section{Donkey isolate}

The results of metacercarial infectivity using the donkey isolate are also summarised in Table 2. Wistar rat susceptibility to donkey isolate of 6-11 week old metacercariae (expressed as \%i) was globally $29.17 \%$. No significant differences were detected between donkey isolate $\% \mathrm{wr}$ and cattle isolate $\% \mathrm{wr}$ for the same age period by the chi-square test $(\alpha: 0.96)$. The global $\%$ wr was 3.96. No significant differences were detected between donkey and cattle isolates \%wr for the same age ranges $(\alpha: 0.20)$.

\section{DISCUSSION}

Metacercarial viability may be tested by physical and/or biological means (Boray 1969). The typical formation of excretory granules and active movement may be observed under the microscope (Boray 1969). Metacercariae can also be excysted in artificial digestive fluids (Over and Dijkstra 1975, Tielens et al. 1981, Luzon-Peña et al. 1995). Over and Dijkstra (1975) 
Table 2. Results obtained in the study of Wistar rats experimentally infected with Fasciola hepatica metacercariae of pig and donkey isolates from the Bolivian Altiplano.

\begin{tabular}{|c|c|c|c|c|c|c|c|c|c|}
\hline \multirow{3}{*}{$\begin{array}{c}\text { Age of } \\
\text { metacercariae } \\
\text { (weeks) }\end{array}$} & \multirow{3}{*}{$\mathrm{m} / \mathrm{r}$} & \multicolumn{3}{|c|}{ Prevalence } & \multicolumn{5}{|c|}{ Intensity } \\
\hline & & \multirow[t]{2}{*}{ nrt } & \multirow[t]{2}{*}{ nri } & \multirow[t]{2}{*}{$\% \mathrm{i}$} & \multirow[t]{2}{*}{ range } & \multirow[t]{2}{*}{$X$} & \multirow[t]{2}{*}{$\% \mathrm{wr}$} & \multicolumn{2}{|c|}{$\%$ wrir } \\
\hline & & & & & & & & range & mean \\
\hline \multicolumn{10}{|c|}{ PIG ISOLATE } \\
\hline 6 & 20 & 5 & 4 & 80.0 & $1-3$ & 2.0 & 8.0 & $5.0-15.0$ & 10.0 \\
\hline 7 & 20 & 3 & 3 & 100 & $1-2$ & 1.3 & 6.7 & $5.0-10.0$ & 6.0 \\
\hline 8 & 20 & 2 & 1 & 50.0 & 1 & 1.0 & 2.3 & 5.0 & 5.0 \\
\hline 9 & 20 & 3 & 1 & 33.3 & 1 & 1.0 & 1.7 & 5.0 & 5.0 \\
\hline 10 & 20 & 4 & 1 & 25.0 & 1 & 1.0 & 1.3 & 5.0 & 5.0 \\
\hline 11 & 20 & 7 & 1 & 14.3 & 1 & 1.0 & 0.7 & 5.0 & 5.0 \\
\hline \multicolumn{10}{|c|}{ DONKEY ISOLATE } \\
\hline 6 & 20 & 3 & 1 & 33.3 & 6 & 6.0 & 10.0 & 30.0 & 30.0 \\
\hline 7 & 20 & 6 & 0 & 0.0 & 0 & 0.0 & 0.0 & 0.0 & 0.0 \\
\hline 9 & 20 & 5 & 2 & 40.0 & $1-3$ & 1.3 & 4.0 & $5.0-15.0$ & 10.0 \\
\hline 10 & 20 & 6 & 3 & 50.0 & $2-3$ & 2.3 & 5.8 & $10.0-15.0$ & 11.7 \\
\hline 11 & 20 & 4 & 1 & 25.0 & 2 & 2.0 & 2.5 & 10.0 & 10.0 \\
\hline
\end{tabular}

$\mathrm{m} / \mathrm{r}=$ number of metacercariae inoculated per rat; $\mathrm{nrt}=$ total number of inoculated rats; nri $=$ number of rats infected; \% $\mathrm{i}=$ percentage of successfully infected rats [(number of rats positive to infection/total number of rats inoculated) $\times 100]$; range $=$ minimum and maximum number of worms recovered per rat; $X=$ mean number of worms recovered per rat; \%wr $=$ total percentage of worms recovered [(total number of flukes recovered/total number of cysts administered in all animals) $\times 100]$; $\%$ wrir range $=$ minimum and maximum percentages of worms recovered per infected rat [(flukes recovered/cysts administered per infected rat $) \times 100]$; \%wrir mean $=$ mean percentages of worms recovered per infected rat [(flukes recovered/cysts administered per infected rat) $\times 100]$.

reported metacercarial survival to be less than $10 \%$ after 330 days, according to the latter method.

Because of the need to evaluate metacercarial viability in order to obtain data for the transmission pattern of the disease on the Northern Bolivian Altiplano, in our case only the most informative biological method, i.e. experimental infection of laboratory animals, has been used.

\section{Influence of metacercarial age}

Most studies on metacercaria testing in laboratory animals have been qualitative and coincide with our results. In a survey of the literature, Boray and Enigk (1964) found that metacercariae can survive for long periods. Shaw (1932) reported that metacercariae aged 335 days and stored at $0^{\circ} \mathrm{C}$ in wet grass are able to infect guinea pig. Boray (1963) found that metacercariae aged 365 days and stored at $2-5^{\circ} \mathrm{C}$ in moist filter paper remain infective in mice.

Unfortunately, however, quantitative studies on metacercarial survival tested in animals are difficult to compare. No standardisation has been developed to define the factors that influence susceptibility to infection, such as the infection technique employed or the experimental host used (with standardised age, sex and body weight). In our study, the infectivity percentages using doses of 20 metacercariae per rat, by which infections were achieved with metacercariae as old as 31 weeks, are greater than those obtained by Meek and Morris (1979) with liver flukes of northern Victoria (Australia) in 10-week old female guinea pigs (the animals were left in the infected area until all the herbage had been consumed). According to these authors, in northern Victoria metacercariae can survive and remain viable for up to 10 weeks on irrigated plots and for up to 9 weeks on non-irrigated plots contaminated in winter (mean temperature $=9.6^{\circ} \mathrm{C}$ ).

The survival of Bolivian metacercariae stored at $4{ }^{\circ} \mathrm{C}$ is greater than the survival reported by Boray and Enigk (1964) in mice (with 5 metacercariae per mouse). When the specimens were kept at $4^{\circ} \mathrm{C}$ for 12 hours each day and at $+10^{\circ} \mathrm{C}$ for the remaining 12 hours, a high proportion remained infective after 70 days. Kimura and Shimizu (1979) showed that Fasciola gigantica metacercariae are infective in rabbits (with 20 metacercariae per rabbit) for at least 180 days after encystment when kept in water at room temperature. The results obtained in the present study show that at high infective doses of one-year old metacercariae, rat infection is possible but gives a very low \%wr.

\section{Influence of liver fluke isolate}

Few data have been reported to date on the infectivity of metacercariae in relation to which definitive host species was the origin of the isolate. Dixon (1964) observed no differences in infectivity or prepatent period between ovine and bovine isolates when using homologous and heterologous hosts. Knight (1978) had similar results using lambs and calves as experimental definitive hosts. Our studies with materials from the Bolivian Altiplano show similar results, so that data from Altiplanic sheep and cattle can be plotted together (Table 1, Fig. 1). 


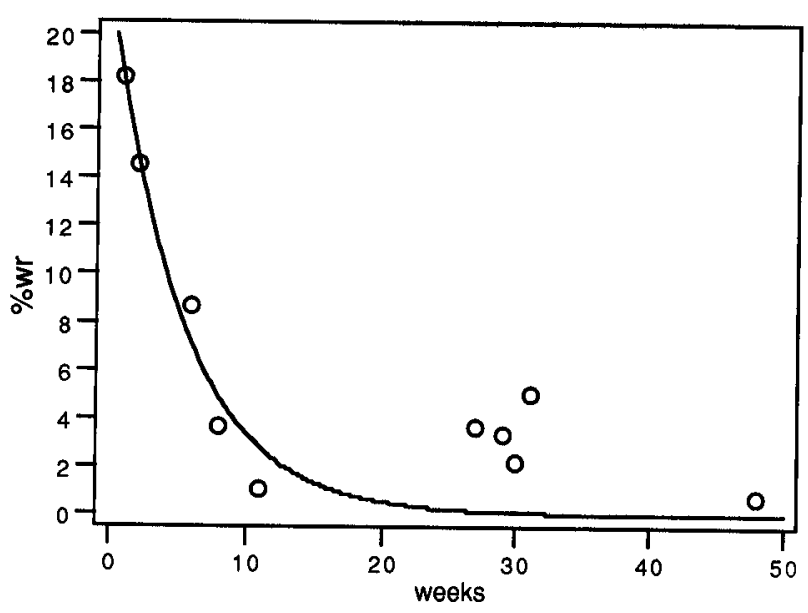

Fig. 1. Fasciola hepatica isolates from sheep and cattle of the Northern Bolivian Altiplano: relationship between the percentage of worms recovered (\%wr) in experimentally infected Wistar rats and metacercarial age in weeks.

Interestingly, our results indicate that metacercarial viabilities of pig and donkey isolates (Table 2) are similar to the viabilities of metacercariae of the main reservoir host isolates (Table 1). It can be consequently deduced that pig and donkey have a high transmission potential capacity concerning this aspect. This fact must be added to the results obtained by Mas-Coma et al.
(1997) which demonstrate that both host species may be considered secondary reservoir hosts of fascioliasis in the Northern Bolivian Altiplano according to their liver fluke infection prevalences and intensities, as well as to their $F$. hepatica egg/host individual/day shedding capacities and population densities in the endemic area. This situation is of great importance for the control of human and animal fascioliasis in this highly endemic zone.

Acknowledgements. This work was supported by funding from the STD Programme of the Commission of the European Communities (DG XII: Science, Research and Development) (Contract No. TS3-CT94-0294), Brussels, EU, the Programme of Scientific Cooperation with Latin America, Instituto de Cooperación Iberoamericana, Agencia Española de Cooperación Internacional (I.C.I.-A.E.C.I.), Madrid, Spain, Project PDP B2/181/125 of the WHO of Geneva, Switzerland, and DGICYT Proyects No. UE96-0001 and PM97-0099 of the Spanish Ministry of Education and Culture, Madrid, Spain. We would like to thank Dr. M.D. Bargues and Dr. I.R. Funatsu (Valencia, Spain) for the collection and rearing of Bolivian lymnaeid snails, for liver fluke infection experiments of snails and by obtaining, keeping and providing the metacercariae used. Dr. J.G. Esteban, Dr. M.D. Bargues and the late Dr. J.A. Oviedo (Valencia, Spain) and Dr. René Angles (La Paz, Bolivia) are acknowledged for technical assistance in the Bolivian slaughterhouses. The authors also acknowledge the facilities provided by the Instituto Nacional de Laboratorios de Salud (INLASA) of La Paz, Bolivia.

\section{REFERENCES}

ALCIBAR MERA P., ANAYA R.M., FLORES-CRESPO R. 1985: Evaluación de la infectividad de miracidios y metacercarias de Fasciola hepatica en bovinos y ovinos con relación a su origen. Téc. Pecu. Méx. 48: 39-45.

BARGUES M.D., MANGOLD A.J., MUÑOZ-ANTOLI C., POINTIER J.-P., MAS-COMA S. 1997: SSU rDNA characterization of lymnaeid snails transmitting human fascioliasis in South and Central America. J. Parasitol. 83: 1086-1092.

BARGUES M.D., MAS-COMA S. 1997: Phylogenetic analysis of lymnaeid snails based on 18S rDNA sequences. Mol. Biol. Evol. 14: 569-577.

BJORLAND J., BRYAN R.T., STRAUSS W., HILLYER G.V., McAULEY J.B. 1995: An outbreak of acute fascioliasis among Aymara Indians in the Bolivian Altiplano. Clin. Inf. Dis. 21: 1228-1233.

BORAY J.C. 1963: The ecology of Fasciola hepatica with particular reference to its intermediate host in Australia. Proc. 17th World Vet. Congr. Hannover, pp. 709-715.

BORAY J.C. 1969: Experimental fascioliasis in Australia. Adv. Parasitol. 8: 95-210.

BORAY J.C., ENIGK K. 1964: Laboratory studies on the survival and infectivity of Fasciola hepatica- and F. gigantica metacercariae. Z. Tropenmed. Parasitol. 15: 324-331.

BUCHON P., CUENCA H., QUITON A., CAMACHO A.M., MAS-COMA S. 1997: Fascioliasis in cattle in the human high endemic region of the Bolivian Northern Altiplano. Res. Rev. Parasitol. 57: 71-83.

CHEN M.G., MOTT K.E. 1990: Progress in assessment of morbidity due to Fasciola hepatica infection: a review of recent literature. Trop. Dis. Bull. 87 (4): R1-R38.

CHOWANIEC W. 1968: Wplyw niektórych czynników srodowiska zewnetrznego na przezywalnosc i inwazyjnosc metacerkarii Fasciola hepatica. Wiad. Parazytol. 14: 529534.

DIXON K.E. 1964: The relative suitability of sheep and cattle as hosts for the liver fluke, Fasciola hepatica L. J. Helminthol. 38: 203-212.

ESTEBAN J.G., BARGUES M.D., MAS-COMA S. 1998: Geographical distribution, diagnosis and treatment of human fascioliasis: a review. Res. Rev. Parasitol. 58: 1348.

ESTEBAN J.G., FLORES A., AGUIRRE C., STRAUSS W., ANGLES R., MAS-COMA S. 1997a: Presence of very high prevalence and intensity of infection with Fasciola hepatica among Aymara children from the Northern Bolivian Altiplano. Acta Trop. 66: 1-14.

ESTEBAN J.G., FLORES A., ANGLES R., MAS-COMA S. 1999: High endemic of human fascioliasis between Lake Titicaca and La Paz valley, Bolivia. Trans. R. Soc. Trop. Med. Hyg. 93: 1-6.

ESTEBAN J.G., FLORES A., ANGLES R., STRAUSS W., AGUIRRE C., MAS-COMA S. 1997b: A population- 
based coprological study of human fascioliasis in a hyperendemic area of the Bolivian Altiplano. Trop. Med. Int. Health 2: 695-699.

FUENTES M.V., COELLO J.R., BARGUES M.D., VALERO M.A., ESTEBAN J.G., FONS R., MAS-COMA S. 1997: Small mammals (Lagomorpha and Rodentia) and fascioliasis transmission in the Northern Bolivian Altiplano endemic zone. Res. Rev. Parasitol. 57: 115-121.

GROCK R., MORALES G., VACA J.L., MAS-COMA S. 1998: Fascioliasis in sheep in the human high endemic region of the Northern Bolivian Altiplano. Res. Rev. Parasitol. 58: 95-101.

HARITH A.E. 1977: Observations on the influence of the intermediate host in experimental fascioliasis. Thesis, Rijksuniversiteit te Utrecht, The Netherlands, $139 \mathrm{pp}$.

HILLYER G.V., SOLER de GALANES M., BUCHON P., BJORLAND J. 1996: Herd evaluation by enzyme-linked immunosorbent assay for the determination of Fasciola hepatica infection in sheep and cattle from the Altiplano of Bolivia. Vet. Parasitol. 61: 211-220.

HILLYER G.V., SOLER de GALANES M., RODRIGUEZPEREZ J., BJORLAND J., SILVA de LAGRAVA M., RAMIREZ GUZMAN S., BRYAN R.T. 1992: Use of the Falcon Assay Screening Test - Enzyme-Linked Immunosorbent Assay (FAST-ELISA) and the Enzyme-Linked Immunoelectrotransfer Blot (EITB) to determine the prevalence of human fascioliasis in the Bolivian Altiplano. Am. J. Trop. Med. Hyg. 46: 603-609.

HODASI J.K.M. 1971: The output of cercariae of Fasciola hepatica by Lymnaea truncatula and the distribution of metacercariae on grass. Parasitology 63: 431-456.

JABBOUR-ZAHAB R., POINTIER J.P., JOURDANE J., JARNE P., OVIEDO J.A., BARGUES M.D., MASCOMA S., ANGLES R., PERERA G., BALZAN C., KHALLAAYOUNE K., RENAUD F. 1997: Phylogeography and genetic divergence of some lymnaeid snails, intermediate hosts of human and animal fascioliasis, with special reference to lymnaeids from the Bolivian Altiplano. Acta Trop. 64: 191-203.

KIMURA S., SHIMIZU A. 1979: Studies on the survival and infectivity of Fasciola gigantica metacercariae. Sci. Rep. Fac. Agric. Kobe Univ. 13: 347-349.

KNIGHT R.A. 1978: Experimental cross infections of Fasciola hepatica in lambs and calves. J. Parasitol. 64: 601-605.

LUZON-PEÑA M., ROJO-VAZQUEZ F.A., GOMEZBAUTISTA M. 1995: Seasonal availability of Fasciola hepatica metacercariae in a temperate Mediterranean area (Madrid, Spain). J. Vet. Med. B42: 577-585.

MAS-COMA S., ANGLES R., ESTEBAN J.G., BARGUES M.D., BUCHON P., FRANKEN M., STRAUSS W. 1999c: The human fascioliasis high endemic region of the Northern Bolivian Altiplano. Trop. Med. Int. Health: 4: 454-467.

MAS-COMA S., ANGLES R., STRAUSS W., ESTEBAN J.G., OVIEDO J.A., BUCHON P. 1995: Human fascioliasis in Bolivia: a general analysis and a critical review of existing data. Res. Rev. Parasitol. 55: 73-93.
MAS-COMA S., BARGUES M.D., ESTEBAN J.G. 1999a: Human fasciolosis. In: J.P. Dalton (Ed.), Fasciolosis. Commonwealth Agricultural Bureaux, UK, pp. 411-434.

MAS-COMA S., BARGUES M.D., MARTY A.M., NEAFIE R.C. 2000: Hepatic trematodiases. In: W.M. Meyers (Ed.), Atlas of Infectious Diseases. U.S. Armed Forces Institute of Pathology, Washington D.C.: in press.

MAS-COMA S., ESTEBAN J.G., BARGUES M.D. 1999b: Epidemiology of human fascioliasis: a review and proposed new classification. Bull. WHO 77: 340-346.

MAS-COMA S., RODRIGUEZ A., BARGUES M.D., VALERO M.A., COELLO J.R., ANGLES R. 1997: Secondary reservoir role of domestic animals other than sheep and cattle in fascioliasis transmission in the Northern Bolivian Altiplano. Res. Rev. Parasitol. 57: 3946.

MEEK A.H., MORRIS R.S. 1979: The longevity of Fasciola hepatica metacercariae encysted on herbage. Aust. Vet. J. 55: $58-60$

O'NEILL S.M., PARKINSON M., STRAUSS W., ANGLES R., DALTON J.P. 1998: Immunodiagnosis of Fasciola hepatica (Fascioliasis) in a human population in the Bolivian Altiplano using purified cathepsin L cysteine proteinase. Am. J. Trop. Med. Hyg. 58: 417-423.

OVER H.J., DIJKSTRA J. 1975: Infection rhythm in fascioliasis In: H.J. Over and J. Armour (Eds.), Facts and Reflections II. Lelystad Workshop on Fascioliasis, pp. 917.

OVIEDO J.A., BARGUES M.D., MAS-COMA S. 1995: Lymnaeid snails in the human fascioliasis high endemic zone of the Northern Bolivian Altiplano. Res. Rev. Parasitol. 55: 35-43.

SAMADI S., ROUMEGOUX A., BARGUES M.D., MASCOMA S., YONG M., POINTIER J.P. 1999: Morphological studies of lymnaeid snails from the human fascioliasis endemic zone of Bolivia. J. Molluscan Stud.: 66: 11-24.

SHAW J.N. 1932: Studies on the liver fluke (Fasciola hepatica). J. Am. Vet. Med. Assoc. 81: 76-82.

SMITH G. 1982: An analysis of variation in the age structure of Fasciola hepatica populations in sheep. Parasitology 84: 49-61.

TIELENS A.G.M., VAN DER MEER P., VAN DER BERGH S.G. 1981: Fasciola hepatica: simple, large-scale, "in vitro" excystment of metacercariae and subsequent isolation of juvenile liver flukes. Exp. Parasitol. 51: 8-12.

UENO H., ARANDIA R., MORALES G., MEDINA G. 1975: Fascioliasis of livestock and snail host for Fasciola in the Altiplano region of Bolivia. Natl. Inst. Anim. Health Q. 15: 61-67.

UENO H., MORALES G. 1973: Fasciolicidal activity of diamphenetide and niclofolan against Fasciola hepatica in sheep in the Altiplano Region of Bolivia. Natl. Inst. Anim. Health Q. 13: 75-79.

VALERO M.A., MARCOS M.D., COMES A.M., SENDRA M., MAS-COMA S. 1999: Comparison of adult liver flukes from highland and lowland populations of Bolivian and Spanish sheep. J. Helminthol. 73: 341-345. 